\title{
Morphogenetic, structural and production traits of marandu grass under nitrogen rates in Neo soil
}

[Características morfogênicas, estruturais e produtivas do capim-marandu sob doses de nitrogênio em Neossolo]

A.B.G. Costa ${ }^{1}$, G.S. Difante ${ }^{1}$, B.A.M. Campelo $^{2}$, A.L.C. Gurgel ${ }^{1 *}$, C.M. Costa ${ }^{1}$, G.F. Theodoro ${ }^{1}$, Á.T.A. Silva ${ }^{2}$, J.V. Emerenciano Neto ${ }^{2}$,

\section{A.M. Dias $^{1}$, P.B. Fernandes ${ }^{1}$}

${ }^{1}$ Universidade Federal de Mato Grosso do Sul - Campo Grande, MS

${ }^{2}$ Universidade Federal do Rio Grande do Norte - Macaíba, RN

\begin{abstract}
Most sandy soils have low natural fertility and low levels of organic matter, making nitrogen $(\mathrm{N})$ fertilization essential. Thus, five doses of $\mathrm{N}$ were applied $\left(0,75,125,175\right.$ and $\left.225 \mathrm{mg} \mathrm{dm} \mathrm{dm}^{-3}\right)$ in a randomized block design to evaluate the effects of nitrogen fertilization on the morphogenetic, structural and production characteristics of Brachiaria brizantha cv. Marandu in a Quartzarenic neosoil. The doses of $\mathrm{N}$ did not affect the height of the canopy. The leaf elongation rate, final leaf length and number of live leaves increased linearly at the doses of N. Leaf appearance rate, stem elongation rate, leaf lifespan, phyllochron, leaf senescence rate and tiller density showed a quadratic response to the rates There was also an effect of $\mathrm{N}$ rates in herbage mass, leaf mass, stem mass, which increased linearly. Brachiaria brizantha cv. Marandu cultivated in Quartzarenic neosoil requires higher doses of N, 175 and $225 \mathrm{mg} \mathrm{dm}-$ 3. Under these conditions, increases in its morphogenetic, structural and productive characteristics are observed. These findings may not be repeated in the most fertile soils with the greatest capacity to supply N.
\end{abstract}

Keywords: fertilization, Brachiaria brizantha, forage, Quartzarenic Neosol, urea

\section{RESUMO}

A maioria dos solos arenosos tem baixa fertilidade natural e baixos teores de matéria orgânica, tornando a adubação com nitrogênio $(N)$ essencial. Assim, foram aplicadas cinco doses de $N(0,75,125,175$ e $225 \mathrm{mg} \mathrm{dm}^{-3}$ ) em delineamento de blocos ao acaso, para se avaliarem os efeitos da adubação com nitrogênio nas características morfogênicas, estruturais e produtivas da Brachiaria brizantha $c v$. Marandu, em um Neossolo Quartzarênico. As doses de N não afetaram a altura do dossel. A taxa de alongamento foliar, o comprimento final da folha e o número de folhas vivas aumentaram linearmente em função das doses de $N$. A taxa de aparecimento de folhas, a taxa de alongamento do caule, o tempo de vida da folha, o filocrono, a taxa de senescência foliar e a densidade de perfilhos apresentaram resposta quadrática às doses de N. A massa da forragem, a massa foliar e a massa do caule aumentaram linearmente. Brachiaria brizantha cv. Marandu cultivada em Neossolo Quartzarênico requer maiores

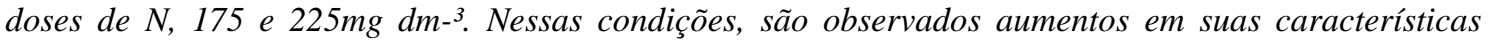
morfogenéticas, estruturais e produtivas. Esses achados podem não se repetir nos solos mais férteis e com maior capacidade de suprir $N$.

Palavras-chave: adubação, Brachiaria brizantha, forragem, Neossolo Quartzarênico, ureia

Recebido em 19 de janeiro de 2021

Aceito em 23 de março de 2021

*Autor para correspondência (corresponding author)

E-mail: antonioleandro09@gmail.com 


\section{INTRODUCTION}

Cultivars of the species Brachiaria brizantha stand out for their persistence and high herbage production capacity (Calvano et al., 2011; Euclides et al., 2019) as well as high phenotypic plasticity in sandy soils and in semiarid environments (Veras et al., 2020). However, for these plants to persist in sandy soils, fertilization management is necessary due to their lower natural fertility (Bezerra et al., 2017). Quartzarenic Neosoils (Quartzipsamments) are very sandy (Freitas et al., 2012), naturally less fertile (Soratto et al., 2011) soils with low waterholding capacity, high erodibility (Zuo et al., 2008), high acidity and low nutrient availability (Silva et al., 2011. Plants grown in this soil type have their nutrient absorption capacity reduced due to rapid leaching and low cation-exchange capacity, which renders Quartzarenic Neosoils less productive (Moura et al., 2017).

Knowledge of the limiting nutritional factors is essential for plants to be able to achieve optimal production capacity (Megda and Monteiro, 2010). In this respect, adequate soil fertility and the maintenance of its chemical attributes are the factors responsible for the formation and development of plants (Aquino et al., 2014). To express their maximum production potential, plants must be adequately supplied with nutrients, mainly nitrogen $(\mathrm{N})$. However, the fraction of $\mathrm{N}$ in the soil resulting from the mineralization of organic matter is not sufficient to meet the requirements of plants in tropical sandy soils (Fagundes et al., 2012; Campos et al., 2020; Clément et al., 2020) Thus, a low supply of $\mathrm{N}$ can compromise the appearance of new tissues (Farias et al., 2019).

In this respect, it is possible that for sandy soils and of low natural fertility, it would be necessary to use higher doses of $\mathrm{N}$ for the plants to express the greatest genetic potential. In this study, we tested the hypothesis that high levels of $\mathrm{N}$ fertilization are required to enhance the agronomic characteristics of Brachiaria brizantha cv. Marandu (marandu grass) in Quartzarenic Neosoils. Therefore, the objective was to examine the effect of $\mathrm{N}$ fertilization rates on the morphogenetic, structural and production traits of marandu grass in a Quartzarenic Neosoil.

\section{MATERIAL AND METHODS}

The experiment was carried out in the experimental area of the Forage Crops Research Group at the Federal University of Rio Grande do Norte (GEFOR-UFRN), located in Macaíba campus - RN, Brazil (5 89'25.78" S; $35^{\circ} 36^{\prime} 37.05^{\prime} \mathrm{W}, 50 \mathrm{~m}$ above sea level). The experimental period was from September 17 (sowing) to December 17, 2018. The climate of the region is dry and sub-humid, with water surplus occurring from May to August (Thornthwaite, 1948). The monthly average precipitation during the experimental period was $35.94 \mathrm{~mm}$ and the minimum, average and maximum temperatures were $24.22^{\circ} \mathrm{C}, 26.88^{\circ} \mathrm{C}$ and $29.66^{\circ} \mathrm{C}$, respectively, data were obtained from the database of the National Institute of Meteorology (Climatologia..., 2020). To ensure its establishment, the crop was irrigated when more than two days passed without rain. The experiment was installed in a randomized block design with five treatments, which consisted of $\mathrm{N}$ doses: $0,75,125,175$ and $225 \mathrm{mg} \mathrm{dm}^{-3}$, which corresponds to $0,150,250,350$ and $450 \mathrm{kgha}^{-1}$ of $\mathrm{N}$, respectively. Applied as urea, and four replications.

Urea was applied with the aid of a pipette in the form of a nutrient solution. The pots were kept in an open environment and used as experimental units. Each pot received $8 \mathrm{dm}^{-3}$ of soil, which corresponded $11.52 \mathrm{~kg}$ of soil. The amount of soil in each pot was calculated based on the soil density $\left(1.44 \mathrm{~kg} \mathrm{dm}^{-3}\right)$ and the volume of the pot $\left(8 \mathrm{dm}^{3}\right)$. The soil, which was classified as a Quartzarenic Neosoil (Teixeira et al., 2018), was collected in the experimental area at a depth of 0 to $20 \mathrm{~cm}$ for analysis. The soil had $91.4 \%$ sand; $4.1 \%$ silt and $4.0 \%$ clay. The soil had $91.4 \%$ sand; $4.1 \%$ silt and $4.0 \%$ clay.

Soil analyzes were performed as described in Teixeira et al. (2018). The $\mathrm{pH}$ was measured in water using the $\mathrm{CaCl} 2$ method (Teixeira et al., 2018). The soil showed the following chemical characteristics: $\mathrm{pH}$ - 5.37; phosphorus - 6.0mg $\mathrm{dm}^{-3}$; potassium - 41.0mg dm ${ }^{-3}$; sodium - $11.0 \mathrm{mg}$ $\mathrm{dm}^{-3}$; calcium - $0.53 \mathrm{cmolc} \mathrm{dm}^{-3}$; magnesium -

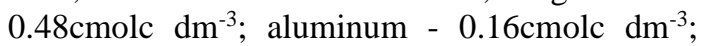
Cation exchange capacity $-4.0 \mathrm{cmolc} \mathrm{dm}^{-3}$. Based on the results of the analysis, time-ofplanting fertilization was carried out using $50 \mathrm{mg}$ $\mathrm{dm}^{-3} \mathrm{P}_{2} \mathrm{O}_{5}$ (single superphosphate) and $50 \mathrm{mg} \mathrm{dm}^{-}$ 
$3 \mathrm{KCl}$ (potassium chloride). This fertilization procedure also included $10 \mathrm{mg} \mathrm{dm}^{-3}$ of micronutrients in the form of FTE-BR12 at $10 \%$, which was later continued in three applications of $30 \%$ performed 30,45 and 60 days after sowing.

Brachiaria brizantha cv. Marandu was sown at a depth of 2 to $3 \mathrm{~cm}$, using 15 seeds per pot. Thinning was carried out on the tenth day after sowing, leaving five plants per experimental unit. The morphogenetic traits were evaluated weekly, starting 15 days after sowing, in three tillers per experimental unit that were chosen at random and identified with colored threads. The following variables were measured: total leaf length (expanded and expanding), number of live leaves (NLL, leaves/tiller) and pseudo stem length (distance from the base of the tiller to the last exposed ligula). With these results, the following variables were determined: final leaf length (FLL,cm tiller ${ }^{-1}$ ), phyllochron (days), leaf appearance rate (LAR, leaves/tiller day), leaf elongation rate (LER, cm/tiller day), stem elongation rate (SER, cm/tiller day), leaf senescence rate (LSR, cm/tiller day) and leaf lifespan (LLS, days) (Chapman and Lemaire, 1993).

Canopy height and tiller density (TD) were measured on the last day of assessment. Height was determined using a ruler graduated in centimeters; five points were measured per pot and the curvature of the leaves was considered as the point of the average height of the canopy. Tiller density was determined by counting all live tillers per pot. To estimate the variables of herbage mass (HM), leaf mass (LM), stem mass (SM) and dead material mass (DMM), the entire aerial part of the plants was cut 90 days after sowing. The samples were used for the separation of the morphological constituents into the following fractions: leaf blade, stem (stem + sheath) and dead material. These components were dried in a forced-air oven at $55^{\circ} \mathrm{C}$ for $72 \mathrm{~h}$ to determine the dry matter.

The roots were washed with running water over 1- and 2-mm-mesh sieves until the adhered soil was removed. Next, they were dried in a forcedair oven at $55^{\circ} \mathrm{C}$ until reaching constant weight and weighed to determine the root DM. Root density was determined by dividing the root DM by the soil volume in each experimental unit.
Data were subjected to analysis of variance. The mathematical model used contained the fixed effect of $\mathrm{N}$ rates and the block. The effect of $\mathrm{N}$ rates was analyzed using regression equations. Linear quadratic models were tested, and the model was selected according to the significance of the regression coefficients, adopting the 5\% probability level and the coefficient of determination $\left(\mathrm{R}^{2}\right)$. The morphogenetic and structural trait data were analyzed by principal components. The data set was standardized, and thus each descriptor had zero mean and variation. This analysis allowed us to reduce the space of original variables into a smaller set and to preserve the maximum of the original variability of the data. All statistical analyses were performed using R software version 3.6.1.

\section{RESULTS}

There was no effect of $\mathrm{N}$ rates $(\mathrm{P}>0.05)$ on canopy height (Table 1). The $\mathrm{N}$ rates induced a linear response in LER, FLL and NLL, which increased by $0.006 \mathrm{~cm} /$ tiller, $0.032 \mathrm{~cm}$ and 0.010 leaves/tiller, respectively, with each milligram of $\mathrm{N}$ added (Table 1). The $\mathrm{N}$ rates had a quadratic effect on LAR, SER, LLS, phyllochron, LSR and TD. Based on the derivative of the equation, the highest LAR (0.09 leaves/tiller day) was estimated at the rate of $150.00 \mathrm{mg} \mathrm{dm}^{-3}$; the highest SER $(0.10 \mathrm{~cm} /$ day $)$ at $83.33 \mathrm{mg} \mathrm{dm}^{-3}$; the highest LLS (110.94 days) at $148.33 \mathrm{mg} \mathrm{dm}^{-3}$; and the highest LSR $(1.43 \mathrm{~cm} /$ day $)$ at the rate of $160.71 \mathrm{mg} \mathrm{dm}^{-3}$ (Table 1 ).

The $\mathrm{N}$ rates did not influence DMM $(\mathrm{P}>0.05$, Table 2). In turn, there was a linear effect of $\mathrm{N}$ rates on $\mathrm{hM}, \mathrm{LM}$ and $\mathrm{SM}$, which increased by $0.188 \mathrm{~g} /$ pot, $0.154 \mathrm{~g} /$ pot and $0.073 \mathrm{~g} /$ pot with each milligram of $\mathrm{N}$, respectively (Table 2). Root $\mathrm{DM}$ and $\mathrm{RD}$ responded quadratically to the increasing $\mathrm{N}$ rates. Five main components (PC) were generated. However, the first PC explained 93\% of the studied variation, and there was an equal distribution between the levels of fertilization with $\mathrm{N}$. CP1, showed that the $\mathrm{N}$ rate of $125 \mathrm{mg} \mathrm{dm}^{-3}$ was neutral in relation to the others (Table 3). This component, also related, the phyllochron and the LLS with the $\mathrm{N}$ rate of $0 \mathrm{mg} \mathrm{dm}^{-3}$. Tiller height, TD, LSR, LAR, LER, FLL, NLL and SER showed a higher correlation with the $\mathrm{N}$ rates of 175 and $225 \mathrm{mg} \mathrm{dm}^{-3}$ (Table 3 ). 
Morphogenetic, structural...

Table 1. Morphogenetic and structural traits of Brachiaria brizantha cv. Marandu under different nitrogen rates in Quartzarenic Neosoil

\begin{tabular}{|c|c|c|c|c|c|c|c|c|c|c|c|c|}
\hline \multirow{2}{*}{ Variable } & \multicolumn{5}{|c|}{$\mathrm{N}$ rate $\left(\mathrm{mg} \mathrm{dm}^{-3}\right)$} & \multirow{2}{*}{$\mathrm{P}$} & \multirow{2}{*}{ SEM } & \multicolumn{2}{|c|}{$P$ value } & \multicolumn{2}{|c|}{$\mathrm{R}^{2}$} & \multirow[b]{2}{*}{ Equation } \\
\hline & 0 & 75 & 125 & 175 & 225 & & & $\mathrm{~L}$ & Q & $\mathrm{L}$ & Q & \\
\hline & & & --Morp & genetic- & & & & & & & & \\
\hline LAR (leaves/ tiller day) & 0.06 & 0.10 & $0.09^{2}$ & 0.10 & 0.10 & 0.005 & 0.005 & 0.001 & 0.047 & 0.57 & 0.73 & $\mathrm{Y}=0.072+0.0003 \mathrm{x}-0.000001 \mathrm{x}^{2}$ \\
\hline LER $(\mathrm{cm} /$ tiller day $)$ & 1.21 & 2.56 & 2.09 & 2.51 & 2.93 & 0.002 & 0.206 & $<0.001$ & 0.228 & 72.22 & 76.20 & $\mathrm{Y}=1.492+0.006 \mathrm{x}$ \\
\hline $\mathrm{SER}(\mathrm{cm} / \mathrm{day})$ & 0.05 & 0.19 & 0.14 & 0.21 & 0.16 & 0.001 & 0.014 & $<0.001$ & $<0.001$ & 44.44 & 76.22 & $Y=0.060+0.001 x-0.000006 x^{2}$ \\
\hline LLS (days) & 133.27 & 107.14 & 117.77 & 114.37 & 114.62 & 0.005 & 3.487 & 0.010 & 0.008 & 31.60 & 65.04 & $Y=130.747-0.267 x+0.0009 x^{2}$ \\
\hline PHY (days/ leaf tiller) & 14.82 & 9.81 & $\begin{array}{c}----S t r \\
10.98\end{array}$ & $\begin{array}{c}\text { tural---- } \\
10.33\end{array}$ & & & 0.498 & & 0.002 & 58.94 & & ( \\
\hline FLL $(\mathrm{cm})$ & 12.06 & 18.36 & 16.72 & 18.09 & 20.87 & 0.001 & 0.924 & $<0.001$ & 0.274 & 77.04 & 79.71 & $\mathrm{Y}=13.300+0.032 \mathrm{x}$ \\
\hline NLL(leaves/ tiller) & 9.11 & 11.16 & 10.91 & 11.33 & 11.91 & 0.007 & 0.395 & 0.001 & 0.177 & 81.09 & 99.36 & $\mathrm{Y}=9.577+0.010 \mathrm{x}$ \\
\hline $\operatorname{LSR}(\mathrm{cm} /$ day $)$ & 0.67 & 1.41 & 1.40 & 1.48 & 1.51 & $<0.001$ & 0.040 & $<0.001$ & $<0.001$ & 70.76 & 93.64 & $Y=0.716+0.009 x-0.00002 x^{2}$ \\
\hline TD (tillers/pot) & 21.66 & 56.50 & 61.50 & 72.25 & 67.50 & $<0.001$ & 3.111 & $<0.001$ & $<0.001$ & 79.17 & 98.19 & $\mathrm{Y}=22.262+0.525 \mathrm{x}-0.001 \mathrm{x}^{2}$ \\
\hline Canopy height $(\mathrm{cm})$ & 12.46 & 23.67 & 22.65 & 24.35 & 24.50 & 0.079 & 2.812 & 0.013 & 0.102 & 67.04 & 91.07 & $\mathrm{Y}=21.52$ \\
\hline
\end{tabular}

LAR: leaf appearance rate; LER: leaf elongation rate; SER: stem elongation rate; LLS: leaf lifespan; PHY: phyllochron; FLL: final leaf length; NLL: number of live leaves; LSR: leaf senescence rate; TD: tiller density. SEM: standard error of the mean.

Table 2. Production variables in Brachiaria brizantha cv. Marandu under different nitrogen rates in Quartzarenic Neosoil

\begin{tabular}{|c|c|c|c|c|c|c|c|c|c|c|c|c|}
\hline \multirow{2}{*}{ Variable } & \multicolumn{5}{|c|}{$\mathrm{N}$ rate $\left(\mathrm{mg} \mathrm{dm}^{-3}\right)$} & \multirow{2}{*}{$P$} & \multirow{2}{*}{ SEM } & \multicolumn{2}{|c|}{$\mathrm{P}$ value } & \multicolumn{2}{|c|}{$\mathrm{R}^{2}$} & \multirow{2}{*}{ Equation } \\
\hline & 0 & 75 & 125 & 175 & 225 & & & $\mathrm{~L}$ & Q & $\mathrm{L}$ & Q & \\
\hline HM (g/pot) & 18.99 & 55.75 & 58.75 & 63.50 & 79.25 & 0.019 & 7.205 & 0.002 & 0.774 & 93.51 & 94.00 & $\mathrm{Y}=35.318+0.188 \mathrm{x}$ \\
\hline LM (g/pot) & 10.66 & 32.50 & 35.50 & 39.00 & 48.75 & 0.003 & 3.525 & $<0.001$ & 0.169 & 91.75 & 95.17 & $Y=14.796+0.154 x$ \\
\hline SM (g/pot) & 5.00 & 16.75 & 16.75 & 18.75 & 23.50 & 0.001 & 2.083 & $<0.001$ & 0.204 & 87.64 & 91.91 & $\mathrm{Y}=7.381+0.073 \mathrm{x}$ \\
\hline DMM (g/pot) & 3.33 & 6.50 & 6.50 & 5.75 & 7.00 & 0.141 & 0.922 & 0.033 & 0.204 & 59.01 & 77.27 & $\mathrm{Y}=5.82$ \\
\hline Root DM (g/pot) & 25.33 & 67.25 & 64.50 & 77.25 & 78.25 & 0.0003 & 5.326 & $<0.001$ & 0.011 & 79.06 & 93.29 & $\mathrm{Y}=27.548+0.520 \mathrm{x}-0.001 \mathrm{x}^{2}$ \\
\hline RD (g/kg soil) & 2.19 & 5.83 & 5.59 & 6.70 & 6.79 & 0.0003 & 0.462 & $<0.001$ & 0.011 & 79.06 & 93.29 & $Y=2.391+0.045 x-0.0001 x^{2}$ \\
\hline
\end{tabular}

Table 3. Principal components (PC) analysis for marandu grass under nitrogen fertilization

\begin{tabular}{|c|c|c|c|c|c|}
\hline & $\mathrm{PC} 1$ & $\mathrm{PC} 2$ & PC3 & PC4 & PC5 \\
\hline Standard deviation & 3.05 & 0.573 & 0.536 & 0.234 & $<0.001$ \\
\hline Proportion of Variance & 0.930 & 0.030 & 0.029 & 0.005 & $<0.001$ \\
\hline \multicolumn{6}{|l|}{ Variable } \\
\hline FLL & 0.315 & -0.438 & -0.200 & 0.053 & 0.514 \\
\hline PHY & -0.326 & -0.019 & -0.124 & 0.311 & -0.436 \\
\hline LAR & 0.313 & -0.386 & 0.354 & 0.195 & 0.040 \\
\hline LER & 0.319 & -0.364 & -0.062 & 0.350 & -0.214 \\
\hline NLL & 0.322 & -0.188 & -0.289 & -0.046 & -0.643 \\
\hline LSR & 0.322 & 0.198 & -0.222 & -0.385 & 0.016 \\
\hline LLS & -0.306 & -0.104 & -0.635 & 0.331 & 0.275 \\
\hline SER & 0.305 & 0.528 & 0.245 & 0.628 & 0.095 \\
\hline TD & 0.310 & 0.356 & -0.459 & 0.141 & 0.020 \\
\hline Height & 0.324 & 0.190 & -0.095 & -0.257 & 0.008 \\
\hline
\end{tabular}

Leaf length (FLL), phyllochron (PHY), leaf appearance rate (LAR), leaf elongation rate (LER), number of live leaves (NLL), leaf senescence rate (LSR), leaf lifespan (LLS), stem elongation rate (SER), tiller density (TD) and height.

\section{DISCUSSION}

Despite the lack of effect for the height of the canopy, the pastures that did not receive fertilization with $\mathrm{N}$, presented height almost $100 \%$ lower than the fertilized pastures, which denotes a positive effect of $\mathrm{N}$ in this variable. In fact, $\mathrm{N}$ promotes an increase in the stalk elongation rate (Table 1), which leads to greater height. The availability of $\mathrm{N}$ for plants is one of the main factors influencing their morphogenetic traits (Bezerra et al., 2020). Leaf appearance rate is highly responsive to $\mathrm{N}$ fertilization, with the absence of this nutrient preventing the appearance of new tillers (Pereira et al., 2010).
Leaf appearance rate is considered the central trait of morphogenesis because it influences the structural components of the forage (Difante $e t$ al., 2011). For each new leaf, a bud is formed with the potential to develop a new tiller (Gastal and Lemaire, 2015). Nitrogen increases the number of dividing cells in meristematic zones, stimulates the production of new cells and induces an increase in LER, NLL and FLL (Farias et al., 2019; Martuscello et al., 2019). Leaf elongation rate is of great relevance to the biomass flow of plants, as it is directly associated with the photosynthetic capacity of plants, having a direct impact on herbage production (Paciullo et al., 2016). 
Phyllochron is defined as the time for the appearance of two consecutive leaves on the tiller (Wilhelm and MCmaster, 1995) corresponding to the inverse of LAR. Therefore, when the plant is fertilized with $\mathrm{N}$, phyllochron is reduced due to the positive effect of $\mathrm{N}$ on LAR (Braz et al., 2010). Unfertilized plants keep their live leaves longer; that is, the increase in $\mathrm{N}$ rates accelerates the senescence process, thereby reducing LLS and increasing LSR (Silva et al., 2015). This explains the higher correlation between the $\mathrm{N}$ rate of 0 and LLS and phyllochron (Table 3).

The leaf development process associated with $\mathrm{N}$ causes the plant to start senescence due to the translocation of nutrients for the expansion of new leaf blades, which accelerates tissue flow (Lemaire et al., 2011; Farias et al., 2019) The response of LSR to $\mathrm{N}$ fertilization was generated by LAR. Number of live leaves is a genetic trait, and when the plant reaches its maximum value for this variable, older leaves begin to senesce to be replaced by new leaves. The increased availability of $\mathrm{N}$ in the soil and, consequently, in the plant cells, enhanced the photosynthetic process. This, in turn, leads to changes in the structural characteristics of the tillers, such as size, weight and appearance rate (Alencar et al., 2010; Gurgel et al., 2020a). These morphogenetic variables directly influence structural variables (Pontes et al., 2003) and promote positive responses in production traits. As a result of this enhancement, the plant will have more leaf area to absorb light, increasing its photosynthetic rate and consequently herbage production (Pilbeam, 2018).

There was no effect of $\mathrm{N}$ rates on DMM (Table 2 ), likely because there was no competition for light. In other words, at 90 days, the plants supposedly had not yet reached the maximum number of live leaves per tiller. That is the moment from which senescence rate could influence the structure and botanical composition of the forage canopy (Difante et al., 2011). Brachiaria cultivars exhibit high plasticity when subjected to stress environments. To ensure their longevity, when in an environment with low $\mathrm{N}$ supply, they prioritize root growth to establish themselves faster. In contrast, under high levels of $\mathrm{N}$, they increase leaf production and tiller growth (Garcez and Monteiro, 2016). The highest root production was observed at the $\mathrm{N}$ rate of $0 \mathrm{mg} \mathrm{dm}^{-3}$, and as the fertilization levels were increased, there was a reduction in root DM and an increase in LM. This compensatory mechanism explains the relationship between $\mathrm{LM}$ and root DM.

The linear effect observed for root DM and RD (Table 2) was due to the relationship between the shoots and the root system, since greater herbage production induces a modulation in the root system to support aerial growth (Bertol et al., 2000; Gurgel et al., 2020b). The remarkable initial rapid growth of the root system is believed to be a mechanism to increase the $\mathrm{N}$ absorbed by these plants (Liao et al., 2004; Noulas et al., 2010), which favors the persistence of grasses in a production system (Garcez and Monteiro, 2016). Therefore, our hypothesis that high levels of $\mathrm{N}$ fertilization are necessary to improve the agronomic characteristics of Brachiaria brizantha cv. Marandu (marandu grass) in quartzarenic neosoil is supported by our data. Although the higher $\mathrm{N}$ rate can benefit the production of marandu grass, it can cause a higher rate of losses and environmental problems. Thus, that in future research the loss rates are quantified to find a balance point to offer suggestions for the use of $\mathrm{N}$ in sandy soils.

\section{CONCLUSIONS}

Brachiaria brizantha cv. Marandu cultivated in Quartzarenic neosoil requires higher doses of $\mathrm{N}$, 175 and $225 \mathrm{mg} \mathrm{dm}^{-3}$. Under these conditions, increases in its morphogenetic, structural and productive characteristics are observed. These findings may not be repeated in the most fertile soils with the greatest capacity to supply $\mathrm{N}$.

\section{ACKNOWLEDGEMENTS}

Authors express great thanks to the financial support from Education Personnel-Brazil (CAPES); National Council for Scientific and Technological Development (CNPq) and support from the Federal University of Mato Grosso do Sul.

\section{REFERENCES}

ALENCAR, C.A.B.; OLIVEIRA, R.A.; CÓSER, A.C. et al. Nitrogen fertilization and annual seasons in the yield irrigated grasses in the Brazil under cut. Rev. Bras. Saúde Prod. Anim., v.11, p.48-58, 2010 . 
AQUINO, R.E.; MARQUES JÚNIOR, J.; CAMPOS, M.C.C. et al. Spatial distribution of soil chemical properties in pasture and forest area. Pesqui. Agropecu. Trop., v.44, p.32-41, 2014.

BERTOL, I.; ALMEIDA, J.A.; ALMEIDA, E.X.; KURTZ, C. Soil physic properties related to forage offer levels of dwarf Elephant grass cv. Mott. Pesqui. Agropecu. Bras., v.35, p.10471054, 2000.

BEZERRA, J.D.V.; EMERENCIANO NETO, J.V.; ALVES, D.J.S. et al. Productive, morfhogenic and structural characteristics of Brachiaria brizantha cultivars grown in two types of soil. Res. Soc. Dev., v.9, e129972947, 2020.

BEZERRA, M.G.S.; SILVA, G.G.C.; DIFANTE, G.S. et al. Cassava wastewater as organic fertilizer in 'Marandu' grass pasture. Rev. Bras. Eng. Agríc. Ambient., v.21, p.404409, 2017.

BRAZ, T.G.S.; FONSECA, D.M.; FREITAS, F.P. et al. Morphogenesis of Tanzania guinea grass under nitrogen doses and plant densities. Rev. Bras. Zootec., v.40, p.1420-1427, 2010.

CALVANO, M.P.C.A.; EUCLIDES, V.P.B.; MONTAGNER, D.B. et al. Tillering and forage accumulation in Marandu grass under different grazing intensities. Rev. Ceres, v.58, p.781-789, 2011.

CAMPOS, C.A.; SUÁREZ, M.G.; LABORDE, J. Analyzing vegetation cover-induced organic matter mineralization dynamics in sandy soils from tropical dry coastal ecosystems. Catena, v.185, p.104-264, 2020.

CHAPMAN, D.F.; LEMAIRE, G. Morphogenic and structural determinants of plant regrowth after defoliation. In: INTERNATIONAL GRASSLAND CONGRESS, 17., 1993, Palmerston North. Proceedings... Palmerston North, New Zealand: Massey University, 1993. p.55-64.

CLÉMENT, C.C.; CAMBOURIS, A.N.; ZIADI, $\mathrm{N}$. et al. Nitrogen source and rate effects on residual soil nitrate and over-winter $\mathrm{NO}_{3}-\mathrm{N}$ losses for irrigated potatoes on sandy soils. Can. J. Soil Sci., v.100, p.44-57, 2020.
CLIMATOLOGIA: mapas. Available in: http://www.inmet.gov.br. Brasília: INMET, 2020. Accessed in: 22 June 2020.

DIFANTE, G.S.; NASCIMENTO JÚNIOR, D.; SILVA, S.C. et al. Morphogenetic and structural characteristics of marandu palisadegrass subjected to combinations of cutting heights and cutting intervals. Rev. Bras. Zootec., v.40, p.955963, 2011.

EUCLIDES, V.P.B.; MONTAGNER, D.B.; MACEDO, M.C.M. et al. Grazing intensity affects forage accumulation and persistence of Marandu palisadegrass in the Brazilian savannah. Grass Forage Sci., v.75, p.1-13, 2019.

FAGUNDES, J.L.; MOREIRA, A.L.; FREITAS, A.W.P. et al. Forage production of Tifton 85 fertilized with nitrogen and subjected to continuous stocking. Rev. Bras. Saúde Prod. Anim., v.13, p.306-317, 2012.

FARIAS, L.N.; ZANINE, A.M.; FERREIRA, D.J. et al. Effects of nitrogen fertilization and seasons on the morphogenetic and structural characteristics of Piatã (Brachiaria brizantha) grass. Rev. Fac. Cienc. Agrar. Uncuyo, v.51, p.42-54, 2019.

FREITAS, I.C.; SANTOS, F.C.V.; CUSTÓDIO FILHO, R.O. et al. Resistance to penetration in Quartzarenic Neosol subjected to different forms of management. Rev. Bras. Eng. Agríc. Ambient., v.16, p.1275-1281, 2012.

GARCEZ, T.B.; MONTEIRO, F.A. Nitrogen use of Panicum and Brachiaria cultivars vary with nitrogen supply: I. Differences in plant growth. Aust. J. Crop Sci., v.5, p.614-621, 2016.

GASTAL, F.; LEMAIRE, G. Defoliation, shoot plasticity, sward structure and herbage utilization in pasture: review of the underlying ecophysiological processes. Agriculture, v.5, p.1146-1171, 2015.

GURGEL, A.L.C.; DIFANTE, G.S.; ARAUJO, A.R. et al. Carbon and nitrogen stocks and soil quality in an area cultivated with guinea grass under the residual effect of nitrogen doses. Sustainability, v.12, e9381, 2020b.

GURGEL, A.L.C.; DIFANTE, G.S.; MONTAGNER, D.B. et al. Nitrogen fertilisation in tropical pastures: what are the impacts of this practice?. Aust. J. Crop Sci., v.14, p.978-984, 2020a. 
LEMAIRE, G.; HODGSON, J.; CHABBI, A. Grassland productivity and ecosystem services. Wallingford: Cabi, 2011. 312p.

LIAO, M.; FILLERY, I.R.P.; PALTA, J.A. Early vigorous growth is a major factor influencing nitrogen uptake in wheat. Funct. Plant Biol., v.31, p.121-129, 2004.

MARTUSCELLO, J.A.; RIOS, J.F.; FERREIRA, M.R. et al. Production and morphogenesis of BRS Tamani grass under different nitrogen rates and defoliation intensities. Indian Anim., v.76, p.1-10, 2019.

MEGDA, M.M.; MONTEIRO, F.A. Nitrogen and potassium supply and the morphogenic and productive characteristics of marandu palisadegrass. Rev. Bras. Zootec., v.39, p.16661675, 2010.

MOURA, C.J.; CREMON, C.; MAPELI, N.C. et al. Quality of a quartzarenic Neosol with and without occurrence of sudden death Brachiaria grass in the Pantanal biome. Agrarian, v.10, p.152-161, 2017.

NOULAS, C.; LIEDGENS, M.; STAMP, P. et al. Subsoil Root growth of field grown spring wheat Genotypes (Triticum Aestivuml.) differing in nitrogen use efficiency parameters. J. Plant Nutr., v.33, p.1887-1903, 2010.

PACIULLO, D.S.C.; GOMIDE， C.A.M.; CASTRO, C.R.T. et al. Morphogenesis, biomass and nutritive value of Panicum maximum under different shade levels and fertilizer nitrogen rates. Grass Forage Sci., v.72, p.590-600, 2016.

PEREIRA, L.E.T.; PAIVA, A.J.; SILVA, S.C. et al. Sward structure of marandu palisadegrass subjected to continuous stocking and nitrogeninduced rhythms of growth. Sci Agric., v.67, p.531-539, 2010.

PILBEAM, D.J. The utilization of nitrogen by plants: a whole plant perspective. Annu. Rev. Plant Bio., v.20, p.305-351, 2018.
PONTES, L.S.; NABINGER, C.; CARVALHO, P.C.F. et al. Morphogenetic and structural traits of ryegrass (Lolium multiflorum Lam.) managed under different sward heights. Rev. Bras. Zootec., v.32, p.814-820, 2003.

SILVA, E.B.; TANURE, L.P.P.; SOUZA, P.T. et al. Growth of the physic nut in quartzarenic neossol by using the missing nutrient technique. Rev. Bras. Fibros., v.14, p.73-81, 2011.

SILVA, E.M.; ANDRADE, A.C.; MAGALHÃES, J.A. et al. Morphogenetic characteristics of the Brachiaria brizantha cv. Marandu submitted to nitrogen doses. PubVet, v.9, p.262-270. 2015

SORATTO, R.P.; SILVA, A.H.; CARDOSO, S.M.; MENDONÇA, C.G. Rates and alternative sources of nitrogen fertilization on maize under no-tillage in sandy soil. Ciênc. Agrotec., v.35, p.62-70, 2011.

TEIXEIRA， P.C.; DONAGEMMA， G.K.; FONTANA, A.; TEIXEIRA, W.G. (Eds.). Manual de métodos de análise de solo. 3.ed. rev. ampl. Brasília, DF: Embrapa, 2018, 573p.

THORNTHWAITE, C.W. An approach toward a rational classification of climate. Geogr Rev., v.38, p.55-94, 1948.

VERAS, E.L.L.; DIFANTE, G.S.; GURGEL, A.L.C. et al. Tillering capacity of Brachiaria cultivars in the Brazilian Semi-Arid Region during the dry season. Trop. Anim. Sci. J., v.43, p.133-140, 2020.

WILHELM, W.W.; MCMASTER, G.S. Importance of the phyllochron in studying development and growth in grasses. Crop Sci., v.35, p.1-3, 1995 .

ZUO, X.; ZHAO, H.; ZHAO, X. et al. Spatial pattern andheterogeneity of soil properties in sand dunes under grazing and restoration inhorqin Sandy Land, Northern China. Soil. Tillage Res., v.99, p.202-212, 2008. 